\title{
EFfects OF Weed Control Through CoWPea InTerCROPPING ON MAYZE MORPHOLOGY AND YIELD ${ }^{1}$
}

\author{
Efeitos do Controle de Plantas Daninhas, por Meio da Consorciação com Feijão-Caupi, na \\ Morfologia e no Rendimento de Cultivares de Milho
}

GOMES, J.K.O. ${ }^{2}$, SILVA, P.S.L. ${ }^{3}$, SILVA, K.M.B. ${ }^{4}$, RODRIGUES FILHO, F.F. ${ }^{5}$ e SANTOS, V.G. ${ }^{6}$

\begin{abstract}
Intercropping combined with competitive maize cultivars can reduce the use of herbicides to control weeds. The objective of this work was to evaluate the effects of intercropping cowpea and maize, as well as hand-weeding on maize morphology and yield. The experimental design was in randomized complete blocks, with treatments arranged in split-plots and five replications. The plots consisted of four maize cultivars (BA 8512, BA 9012, EX 4001, EX 6004) and the split-plots consisted of the following treatments: no-weeding; twice hand-weeding (20 and 40 days after sowing); and intercropping with cowpea ('Sempre Verde' cultivar), both maize and cowpea sown at the same time. The variables evaluated were: maize fresh green ears and grain yield; characteristics of internodes, leaves, tassels, ears, grains; plant height and ear insertion height; number of weed plants and species; fresh and dry biomass of weed species and cowpea. Ten weed species were outstanding during the experiment, many of them from the Poaceae family. No interactions were found between weed control method and maize cultivars for most variables evaluated; and plants from hand-weeded split-plots showed superior mean values compared to plants from nonweeded and intercropped split-plots, both not differing from each other. The cowpea was inefficient in controlling weed, reducing the maize yields and not producing any grain. The maize cultivars 'BA 8512' and 'BA 9012 showed the highest mean green ear yield, and the highest grain yield in hand-weeded, no-weeded and intercropped split-plots. On the other hand, the maize cultivar 'EX 6004' showed such high means only in no-weeded and intercropped split-plots. 'EX 4001 presented the worst means in these variables for handweeded, no-weeded ant intercropped split-plots
\end{abstract}

Keywords: Zea mays L., green ears, grain yield, competition, Vigna unguiculata (L) Walp.

RESUMO - A consorciação aliada ao uso de cultivares de milho mais competitivosé um método que permite reduzir o uso de herbicidas para controle de plantas daninhas. O objetivo deste trabalho foi avaliaros efeitos do uso do caupi, em consorciação, e de capinas sobre a morfologia e o rendimento de cultivares de milho. Utilizou-se o delineamento em blocos casualizados, com tratamentos dispostos em parcelas subdivididas e cinco repetições. Quatro cultivares de milho (BA 8512, BA 9012, EX 4001 e EX 6004) foram aplicados às parcelas e submetidos aos seguintes tratamentos: sem capinas; duas capinas (aos 20 e 40 dias após o plantio); e consorciação com o caupi (cultivar Sempre Verde), plantado por ocasião do plantio do milho, entre as fileiras da gramínea. Foram avaliados os rendimentos de espigas verdes e de grãos; as características de entrenós, folhas, pendões, espigas e grãos; as alturas da planta e de inserção da espiga; o número de espécies e de

\footnotetext{
1 Received for publication on 12.12.2006 and accepted in the revised form on 10.7.2007.

2 Universidade Federal do Semi-Árido (UFERSA), Caixa Postal 137, 59625-900, Mossoró-RN <jorge@alunos.esam.br>; ${ }^{3}$ UFERSA, <paulosergio @ ufersa.edu.br> (corresponding author); ${ }^{4}$ Universidade do Estado do Rio Grande do Norte (UERN). Caixa Postal 70, 59600-970 Mossoró-RN, <kathiafanat@ uern.br>; ${ }^{5}$ EMBRAPA- Researcher - Meio Norte. Av. Duque de Caxias, 5650,64006-220 Teresina-PI, <freire@ cpamn.embrapa.br>; ${ }^{6}$ Agronomy undergraduate student - UFERSA, <vivian@alunos.esam.br>.
}

Planta Daninha, Viçosa-MG v. 25, n. 3, p. 433-441, 2007 
plantas por unidade de área das plantas daninhas; e a biomassafresca e seca das plantas daninhas e do feijão-caupi. Dez espécies de plantas daninhas predominaram no experimento, com destaque para a família Poaceae. Na maioria das características, não se verificou interação entre métodos de controle de plantas daninhas e cultivares, e as plantas das parcelas capinadas foram superiores (mais produtivas e com maiores médias nas outras características avaliadas) àquelas das parcelas não-capinadas e das parcelas consorciadas, as quais não diferiram entre si. Portanto, o feijãocaupi foi ineficiente no controle das plantas daninhas, não produziu grãos e reduziu os rendimentos do milho. Os cultivares de milho BA 8512 e BA 9012 apresentaram os maiores rendimentos de espigas verdes e de grãos nas subparcelas capinadas, não-capinadas e consorciadas. Por sua vez, o cultivar EX 6004 apresentou as maiores médias nessas caracteristicas apenas nas parcelas não-capinadas e consorciadas. O cultivar EX 4001 foi o pior nas referidas características, nos três tipos de subparcelas.

Palavras-chave: Zea mays L., milho verde, produtividade, competição, Vigna unguiculata (L) Walp.

\section{INTRODUCTION}

The increasing crop productivity observed during the last century was the result of plant breeding and application of new crop management technologies. Many of these technologies consisted of using chemical products, mainly fertilizers, pesticides and herbicides. However, agrochemicals have also led to environmental damages such as soil and water pollution, plant pathogen and pest resistance, as well as weed resistance and less healthy plant food for mankind. Due to the increasing concern about environmental preservation and human health, several crop managements adopted in the past are presently being reviewed and new alternatives are being tested and evaluated.

The diversification of crop systems by increasing the number of cultivated species in the same or nearby areas has been proposed for the solution of such problems of modern agriculture. Intercropping, which is the practice of cultivating two or more species simultaneously in the same field area, is one option for cropping diversification (Vandermeer et al., 1998). The adoption of the intercropping system is usually justified by the better use of environmental resources as compared to monocropping (Fukai \& Trenbath, 1993). In addition, intercropping is also indicated as an alternative to the use of herbicides, by reducing or suppressing weed growth (Liebman \& Davis, 2000). Weed biomass in intercropped plots decreased in 47 field experiments, increased in four of them and varied in three other ones, compared to monocropped plots (Liebman \& Davis, 2000). Decreased weed incidence on maize by means of intercropping is dependent on several factors, such as type of maize cultivar, climate conditions (Kuchinda et al., 2003); sowing period, intercropped species (Skóra Neto, 1993); and fertilizer rates (Olasantan et al., 1994). Intercropping systems might be more advantageous than monocropping systems due to their more efficient competition for the available resources or to their alellophatic effect on weeds. Alternatively, intercropping systems might also use resources not exploited by weeds or might better convert such resources to the economic part of the crop than monocropping would (Liebman \& Dyck, 1993). In northeastern Brazil, maize intercropped with cowpea (Vigna unguiculata, L. Walp.) is an extensively used practice, although weed has not been the main goal but rather, better utilization of environmental resources. Hence, evaluation of weed control in maize by means of cowpea intercropping is of great concern.

Another way of reducing herbicide application is the use of more competitive maize cultivars that can more effectively use light, water and nutrients in the presence of weeds (Ford \& Pleasant, 1994). Variety differences in the ability to suppress weeds have been reported for cotton, potatoes, soybeans (Callaway, 1992) and maize (Rossi et al., 1996; Begna et al., 2001; Callaway, 1992). Early maize hybrids tolerated severe infestations of Setaria glauca, L.P. Beauv. 
better than the late ones (Staniforth, 1961). In addition, it was observed that under high weed infestation pressure and high nitrogen rate, a "modern" maize hybrid presented a lower yield decay $(11 \%)$ than an "old" one $(17 \%)$ (Tollenaar et al., 1994). The higher yielding losses of the "old" maize hybrid were attributed to its lower $\mathrm{N}$-use efficiency, lower leaf area index (LAI) and lower photosynthetic photon flow density. Plant height, LAI, leaf area expansion rate and shoot leaf area distribution are some of the main characteristics of plants involved in competition for light (Sinoquet \& Caldwe1l, 1995). Such features can be improved through plant genetic breeding and/ or changes in crop management practices such as plant spacing or plant population (Lindquist \& Mortensen, 1998). These strategies can result in maize plants that better compete with weeds and, consequently, might help producers reduce the amount of herbicides required to control weeds, consequently reducing the environmental damages (Begna et al., 2001).

The objective of this research was to evaluate the use of cowpea intercropped with maize and hand-weeding on weed incidence, yielding and morphology of green ears and grains of four maize cultivars.

\section{MATERIAL AND METHODS}

The experimental area soil was classified according to the Brazilian Soil Classification System as Eutrophic Red Yellow Argisol (Embrapa, 1999) which showed the following chemical analysis results (Brazil, 1997): $\mathrm{pH}=6.8 ; \mathrm{P}=25.0 \mathrm{mg} \mathrm{dm}^{-3} ; \mathrm{K}^{+}=0.10 \mathrm{cmol}_{\mathrm{c}} \mathrm{dm}^{-3}$; $\mathrm{Ca}^{2+}=1.80 \mathrm{cmol}_{\mathrm{c}} \mathrm{dm}^{-3} ; \mathrm{Mg}^{2+}=0.40 \mathrm{cmol}_{\mathrm{c}} \mathrm{dm}^{-3}$; $\mathrm{Al}^{3+}=0.00 \mathrm{cmol}_{\mathrm{c}} \mathrm{dm}^{-3} ; \mathrm{Na}^{+}=0.01 \mathrm{cmol}_{\mathrm{c}} \mathrm{dm}^{-3}$ and organic matter $=1.90 \mathrm{~g} \mathrm{~kg}^{-1}$. The soil was twice prepared with leveling disk and received the following fertilization before sowing (in $\left.\mathrm{kg} \mathrm{ha}^{-1}\right): 30 \mathrm{~kg}$ of $\mathrm{N}$ (1/3 of total $\mathrm{N}$ applied), $60 \mathrm{~kg}$ of $\mathrm{P}_{2} \mathrm{O}_{5}$ and $30 \mathrm{~kg}$ of $\mathrm{K}_{2} \mathrm{O}$. After sowing, $60 \mathrm{~kg} \mathrm{~N} \mathrm{ha}{ }^{-1}$ was sidedressed, half after 21 days and half after 41 days. Nitrogen, phosphorus and potassium were applied as ammonium sulfate, simple superphosphate and potassium chloride, respectively.

The experiment was arranged in a randomized complete block design, in split- plots, with five replications. The main plots consisted of four maize cultivars: BA 8512, BA 9012, EX 4001, EX 6004. And the split-plots consisted of the following treatments: noweeding; twice hand-weeding, at 20 and 40 days after sowing; intercropping with cowpea, 'Sempre Verde' cultivar, both maize and cowpea seeded at the same time. Maize was seeded in rows March 21, 2004, using four seeds at each $0.40 \mathrm{~m}$ and $1.0 \mathrm{~m}$ spaced rows. At 20 days after sowing, the best two seedlings were left per hole. Hand weeding was carefully performed in each plot. Each subplot consisted of four $6.0 \mathrm{~m}$-long rows, but only the two central rows were considered as experimental plots, by discarding the border rows and the two plants at each row extremity.

Control of fall armyworm (Spodoptera frugiperda Smith), the main maize pest in the region, was accomplished with two sprayings of deltamethrin $\left(250 \mathrm{~mL} \mathrm{ha}^{-1}\right), 7$ and 14 days after sowing.

The experimental area was spray-irrigated with the sprayer set disposed perpendicularly to the experimental plots. The water lamina required for maize crop $(5.6 \mathrm{~mm})$ was calculated considering $0.40 \mathrm{~m}$ as the effective root depth. Irrigation time was estimated through water retention at $0.40 \mathrm{MPa}$ soil tension.

The following variables were evaluated in maize plants, based on randomized samplings obtained from the central rows of each plot: plant height $=$ distance from the soil level up to the highest leaf insertion; and ear insertion height $=$ distance from the soil level up to the highest ear insertion (both measured in ten plants, at the harvest time of dry plants); internode number, length and diameter; leaf area (evaluated in three plants after green ear harvest; tassel branch number, length and dry biomass (from three plants); green ear yield (green ears from one central row); grain yield (kg ha ${ }^{-1}$, grain humidity corrected for $15.5 \%$ humidity) and number of ears (per ha), determined from mature ears from one central row, and estimated for one hectare based on the useful subplot area; number of grains per ear; number of grain-rows per ear; ear and cob diameter (from a ten-ear sample); 100-seed weight (ten samples of $100 \mathrm{~g}$ ); grain width, height and thickness (from 20 grain 
sample). Tassel dry biomass was obtained after sample drying in a forced-air oven at $75^{\circ} \mathrm{C}$ until constant mass. Leaf area was evaluated using a leaf area meter LI 3100 (LI-COR Inc.). Length and width of leaves, and length of internodes were measured using a ruler; diameter of internodes was determined with a caliper. Green ear yielding was evaluated in one central row of each subplot, at random, for the following variables: number and mass of marketable ears with and without husks; grading (selection and classification) of marketable ears with husks according to their appearance and length $(\geq 0.22 \mathrm{~m})$; grading (selection and classification) of ears without husks according to their sanity, grain formation and length $(>0.17 \mathrm{~m})$; length, diameter and number of ear husks.

The cowpea plants were evaluated after dry corn harvest. Cowpea fresh biomass was obtained from two plants taken at random from the central area of the intercropped subplots; a 500g-sample was taken for dry matter determination (following the same procedures described above for tassels).

The intercropped and non-weeded subplots were evaluated for the weeds present in the experiment, and the following variables were registered: number of weed species and weed plant dry matter. Plants were collected from a square area of $0.50 \times 0.50 \mathrm{~m}$, between the two central rows and the two central holes of maize plants, for dry matter determination (following the same procedures described above for tassels).

The data were submitted to analyses of variance using the software developed at the Universidade Federal de Viçosa (UFV), MG, Brazil (Ribeiro Júnior, 2001) and means compared by the Tukey test $(\mathrm{P}<0.05)$.

\section{RESULTS AND DISCUSSION}

Only ten weed species were found in the experiment, many of which belonged to the Poaceae family: Alternanthera ficoidea (L.) P. Beauv. (slender joyweed, Amaran thaceae), Borreria verticillata (L.) G.F.W. Meyer. (white Broom, Rubiaceae), Cenchrus echinatus L. (southern sandbur, Gramineae), Commelinasp. L. (dayflower, Commelinaceae), Cucumis anguria L. (gherkin, Cucurbitaceae), Dactyloctenium aegyptium (L.) Beauv. (c row fo ot grass, Gram in eae), Digitaria sanguinalis (L.) Scop. (crabgrass, Gramineae), Melochia pyramidata L. (pyramid flower, Sterculiaceae), Phyllanthus niruri L. (gale of the wind, Euphorbiaceae) and Senna uniflora (P.Mill) Irwin \&Barneby (oneleaf senna, Fabaceae, Leguminosae). This low number of species might probably be associated to the intensive maize cropping in the area during the last ten years (two cultivations per year involving disk leveling and fertilization). Usually, weed biomass production, as well as plant diversity and density are lower under conventional cultivation (intensive soil preparation and high rates of agrochemicals), intermediary under minimum tillage system and highest under the organic system (Menalled et al., 2001). Weed population in a specific area depends on several factors and although such population is composed of different species, few usually dominate, corresponding to $70 \%-90 \%$ of the total species (Buhler, 1999).

For most variables evaluated, there was no interaction between the cultivars and the weeding treatments. For this reason, only the means of the main effects within each treatment group are presented and discussed in this paper.

No differences (main effect means) were found between the no weeding and cowpea intercropping treatments for weed fresh and dry biomass and number of weed plants per unit area $\left(\mathrm{m}^{2}\right)$ (Table 1$)$. The mean comparisons for the same weed variables among the maize cultivar plots did not show any significant difference $(\mathrm{CVa}=28 \%, 22 \%$ and $32 \%$, respectively). Similar results have been reported by Ford \& Pleasant (1994), who found no differences among plots cultivated with different maize hybrids concerning weed plant number per unit area or biomass. In this research, cowpea shoot fresh matter (mean of $10.345 \mathrm{~kg} \mathrm{ha}^{-1}$ and $\mathrm{CVa}=55 \%$ ) and dry matter (mean of $2.152 \mathrm{~kg} \mathrm{ha}^{-1}$ and $\mathrm{CVa}=77 \%$ ) yields were different among maize cultivar plots.

Maize 'BA 8512' presented shorter average

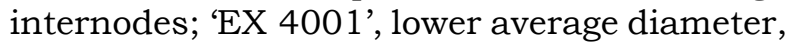
and 'EX 4001' showed also shorter leaves. However, the cultivars did not differ as to 
average leaf width (Table 2). Since all cultivars presented similar leaf width, it is obvious that cultivars with longer leaves also showed higher leaf areas and 'EX 6004' (with shorter leaves), lower leaf areas. 'EX 6004' also presented the highest plants and ear insertions (Table 2). In relation to tassel characteristics, 'EX 4001' showed the lowest values for number and length of tassel branches while 'BA 8512' showed the lowest tassel dry biomass (Table 2). It is evident that tassel dry biomass is dependent on other characteristics than the ones evaluated, such as, for example, flower number.

Higher values for internode diameter; leaf length, width and area; plant height; and tassel branch number, length and biomass were observed in the hand-weeded subplots compared to the non-weeded and intercropped subplots, except for internode length and ear insertion height for which no differences were found among the three treatment groups (Table 3). Similarly to this research results, other authors reported lower maize plant height due to the presence of weeds (Begna et al., 2001; Rossi et al., 1996), but contrarily to this experiment, these authors also observed reduced ear insertion height. Furthermore, it was observed that maize plants from nonweeded and intercropped subplots frequently showed lower number of internodes and, consequently, lower number of leaves compared to the hand-weeded subplots (data not showed). This is corroborated by the observations of Begna et al. (2001). Decreased maize stem diameter due to the presence of weeds has also been reported (Souza, 1994) as well as reduced maize leaf area (Aflakpui et al., 2002).

Overall, maize cultivars did not differ in number and mass of marketable ears with husks, average diameter of ears with husks, average length of ears without husks and average number of husks per ear (Table 4). But 'BA 8512' showed the highest number and mass of marketable ears without husks; 'EX 4001' showed the largest diameter for ears without husks; and 'EX 6004', the longest ears with husks (Table 4).

Cowpea in tercropping effect on the evaluated green ear characteristics was

Table 1 - Characteristics of weed plants collected in the maize cultivated plots submitted to no-weeding and intercropped with cowpea $^{1}$

\begin{tabular}{|l|c|c|c|}
\hline \multirow{2}{*}{ Weed control method } & \multirow{2}{*}{ Plant number $\mathrm{m}^{-2}$} & Fresh & Dry \\
\cline { 3 - 4 } & & $1504 \mathrm{~b}$ & $218 \mathrm{~b}$ \\
\hline Hand-weeding & $24.3 \mathrm{~b}$ & $3343 \mathrm{a}$ & $516 \mathrm{a}$ \\
\hline No-weeding & $54.2 \mathrm{a}$ & $2771 \mathrm{a}$ & $408 \mathrm{a}$ \\
\hline Intercropped with cowpea & $50.4 \mathrm{a}$ & 33 & 36 \\
\hline $\mathrm{CVb}(\%)$ & 36 & $\left.\mathrm{~g} \mathrm{~m}^{-2}\right)$ \\
\hline
\end{tabular}

${ }^{1 /}$ Means followed by the same letters in the column do not differ by the Tukey's test at $\mathrm{P}<0.05$.

Table 2 - Length and diameter of internodes (average of the 11 upper internodes); leaf length, width and area (average of the 7 upper leaves); plant height, ear insertion height and tassel characteristics of four maize cultivars from field subplots under different weed control methods (means over weed control methods) ${ }^{1 /}$

\begin{tabular}{|c|c|c|c|c|c|c|c|c|c|c|}
\hline \multirow[b]{2}{*}{ Maize Cultivar } & \multicolumn{2}{|c|}{ Internodes } & \multicolumn{3}{|c|}{ Leaf } & \multicolumn{2}{|c|}{ Plant and ear height } & \multicolumn{3}{|c|}{ Tassel } \\
\hline & $\begin{array}{l}\text { Length } \\
(\mathrm{cm})\end{array}$ & $\begin{array}{l}\text { Diam. } \\
(\mathrm{mm})\end{array}$ & $\begin{array}{l}\text { Length } \\
(\mathrm{cm})\end{array}$ & $\begin{array}{l}\text { Width } \\
(\mathrm{cm})\end{array}$ & $\begin{array}{l}\text { Area } \\
\left(\mathrm{cm}^{2}\right)\end{array}$ & $\begin{array}{l}\text { Plant } \\
(\mathrm{cm})\end{array}$ & $\begin{array}{l}\text { Ear } \\
(\mathrm{cm})\end{array}$ & $\begin{array}{c}\text { Branches } \\
\#\end{array}$ & $\begin{array}{c}\text { Average } \\
\text { branch length } \\
(\mathrm{cm})\end{array}$ & $\begin{array}{l}\text { Dry biomass } \\
\left(\mathrm{g} \mathrm{tassel}^{-1}\right)\end{array}$ \\
\hline BA 8512 & $13.0 \mathrm{~b}$ & $108 \mathrm{a}$ & $65.7 \mathrm{a}$ & $6.9 \mathrm{a}$ & $270 \mathrm{a}$ & $160 \mathrm{~b}$ & $72 \mathrm{ab}$ & $8.4 \mathrm{ab}$ & $19.3 \mathrm{a}$ & $1.9 \mathrm{~b}$ \\
\hline BA 9012 & $14.2 \mathrm{a}$ & $109 \mathrm{a}$ & $64.1 \mathrm{a}$ & $6.7 \mathrm{a}$ & $258 \mathrm{ab}$ & $157 \mathrm{~b}$ & $69 \mathrm{~b}$ & $9.1 \mathrm{a}$ & $18.5 \mathrm{a}$ & $2.1 \mathrm{ab}$ \\
\hline EX 4001 & $14.0 \mathrm{a}$ & $96 \mathrm{~b}$ & $54.2 \mathrm{~b}$ & $6.7 \mathrm{a}$ & $217 \mathrm{~b}$ & $153 \mathrm{~b}$ & $69 \mathrm{~b}$ & $7.8 \mathrm{~b}$ & $16.8 \mathrm{~b}$ & $2.0 \mathrm{ab}$ \\
\hline EX 6004 & $14.4 \mathrm{a}$ & $106 \mathrm{ab}$ & $67.1 \mathrm{a}$ & $6.6 \mathrm{a}$ & $273 \mathrm{a}$ & $174 \mathrm{a}$ & $77 \mathrm{a}$ & $9.6 \mathrm{a}$ & $20.1 \mathrm{a}$ & $2.3 \mathrm{a}$ \\
\hline $\mathrm{CVa}(\%)$ & 7 & 11 & 5 & 9 & & 5 & 6 & 13 & 8 & 12 \\
\hline
\end{tabular}

$\stackrel{1}{ }$ Means followed by the same letters in the column do not differ by the Tukey's test at $\mathrm{P}<0.05$. 
equivalent to the non-weeded subplots, i.e., low green ear values were found in both intercropped and non-weeded treatments, compared to the weeded subplots, except for husk number per ear (Table 5). Silva et al. (2004) have also observed reduced maize green ear yield due to weed competition.

As for ear and grain characteristics, differences were found among maize cultivars as to number of grain-rows per ear, number of grains per ear, 100-seed weight and grain width (Table 6). 'BA 8512' ranked best for the two first characteristics and 'EX 6004', for the last ones.

In the weed-free-plots, the maize plants showed higher mean values for all the ear and grain characteristics, except for grain thickness and width, compared to the other plots, which did not differ from each other (Table 7). There were no differences among the several weeding treatments for grain thickness and width. Larger cob diameters and grain widths can explain the larger ear diameters presented for the plants from the

Table 3 - Length and diameter of internodes (average of the 11 upper internodes), leaf length, width and area (average of the 7 upper leaves), plant height, ear insertion height and tassel characteristics of four maize cultivars from field subplots under different weed control methods (means over maize cultivars) ${ }^{1}$

\begin{tabular}{|c|c|c|c|c|c|c|c|c|c|c|}
\hline \multirow{2}{*}{ Weed control methods } & \multicolumn{2}{|c|}{ Internodes } & \multicolumn{3}{|c|}{ Leaf } & \multicolumn{2}{|c|}{$\begin{array}{c}\text { Plant and ear } \\
\text { height }\end{array}$} & \multicolumn{3}{|c|}{ Tassel } \\
\hline & $\begin{array}{l}\text { Length } \\
(\mathrm{cm})\end{array}$ & $\begin{array}{l}\text { Diam. } \\
(\mathrm{mm})\end{array}$ & $\begin{array}{l}\text { Length } \\
(\mathrm{cm})\end{array}$ & $\begin{array}{c}\text { Width } \\
(\mathrm{cm})\end{array}$ & $\begin{array}{l}\text { Area } \\
\left(\mathrm{cm}^{2}\right)\end{array}$ & $\begin{array}{l}\text { Plant } \\
(\mathrm{cm})\end{array}$ & $\begin{array}{l}\text { Ear } \\
(\mathrm{cm})\end{array}$ & $\begin{array}{c}\text { Branches } \\
\#\end{array}$ & $\begin{array}{l}\text { Average branch } \\
\text { length }(\mathrm{cm})\end{array}$ & $\begin{array}{c}\text { Dry biomass } \\
\left(\mathrm{g} \mathrm{tassel}^{-1}\right)\end{array}$ \\
\hline Hand-weeding & $14.4 \mathrm{a}$ & $114 \mathrm{a}$ & $69.6 \mathrm{a}$ & $7.1 \mathrm{a}$ & $325 \mathrm{a}$ & $168 \mathrm{a}$ & $74 \mathrm{a}$ & $9.8 \mathrm{a}$ & $19.9 \mathrm{a}$ & $2.6 \mathrm{a}$ \\
\hline No-weeding & $13.7 \mathrm{a}$ & $100 \mathrm{~b}$ & $59.2 \mathrm{~b}$ & $6.5 \mathrm{~b}$ & $223 \mathrm{~b}$ & $156 \mathrm{~b}$ & $70 \mathrm{a}$ & $8.3 \mathrm{~b}$ & $18.0 \mathrm{~b}$ & $1.8 \mathrm{~b}$ \\
\hline Intercroped with cowpea & $13.6 \mathrm{a}$ & $100 \mathrm{~b}$ & $59.6 \mathrm{~b}$ & $6.2 \mathrm{~b}$ & $216 \mathrm{~b}$ & $159 \mathrm{~b}$ & $71 \mathrm{a}$ & $8.1 \mathrm{~b}$ & $18.2 \mathrm{~b}$ & $1.9 \mathrm{~b}$ \\
\hline $\mathrm{CVb}(\%)$ & 8 & 12 & 9 & 7 & 18 & 6 & 9 & 16 & 9 & 20 \\
\hline
\end{tabular}

$\downarrow$ Means followed by the same letters in the column do not differ by the Tukey's test at $\mathrm{P}<0.05$.

Table 4 - Green ear yield, length and diameter of four maize cultivars from field subplots under different weed control methods (means over method of weed control) ${ }^{\mathrm{V}}$

\begin{tabular}{|c|c|c|c|c|c|c|c|c|c|}
\hline \multirow{2}{*}{ Maize Cultivar } & \multicolumn{2}{|c|}{$\begin{array}{c}\text { Marketable green ears with } \\
\text { husks }\end{array}$} & \multicolumn{2}{|c|}{$\begin{array}{c}\text { Marketable green ears } \\
\text { without husks }\end{array}$} & \multicolumn{2}{|c|}{$\begin{array}{l}\text { Ear diameter } \\
(\mathrm{cm})\end{array}$} & \multicolumn{2}{|l|}{ Ear length } & \multirow{2}{*}{$\begin{array}{l}\text { Number of of } \\
\text { husks per ear }\end{array}$} \\
\hline & Number ha ${ }^{-1}$ & $\begin{array}{c}\text { Yield } \\
\left(\mathrm{kg} \mathrm{ha}^{-1}\right)\end{array}$ & $\begin{array}{c}\text { Number } \\
\text { ha }^{-1}\end{array}$ & $\begin{array}{c}\text { Yield } \\
\left(\mathrm{kg} \mathrm{ha}^{-1}\right)\end{array}$ & $(+)$ husks & $(-)$ husks & (+) husks & $(-)$ husks & \\
\hline BA 8512 & $32.731 \mathrm{a}$ & $7.867 \mathrm{a}$ & $27.095 \mathrm{a}$ & $4.949 \mathrm{a}$ & $5.3 \mathrm{a}$ & $4.3 \mathrm{~b}$ & $27.2 \mathrm{~b}$ & $17.8 \mathrm{a}$ & $10.0 \mathrm{a}$ \\
\hline BA 9012 & $29.895 \mathrm{a}$ & $6.474 \mathrm{a}$ & $21.916 \mathrm{ab}$ & $3.891 \mathrm{ab}$ & $5.1 \mathrm{a}$ & $4.4 \mathrm{ab}$ & $27.4 \mathrm{~b}$ & $17.5 \mathrm{a}$ & $10.0 \mathrm{a}$ \\
\hline EX 4001 & $25.212 \mathrm{a}$ & $5.976 \mathrm{a}$ & $20.382 \mathrm{~b}$ & $3.675 \mathrm{ab}$ & $5.2 \mathrm{a}$ & $4.5 \mathrm{a}$ & $27.9 \mathrm{~b}$ & $17.9 \mathrm{a}$ & $9.7 \mathrm{a}$ \\
\hline EX 6004 & $28.676 \mathrm{a}$ & $6.446 \mathrm{a}$ & $21.707 \mathrm{ab}$ & $3.073 \mathrm{~b}$ & $5.2 \mathrm{a}$ & $4.1 \mathrm{c}$ & $30.0 \mathrm{a}$ & $17.6 \mathrm{a}$ & $11.0 \mathrm{a}$ \\
\hline $\mathrm{CVa}(\%)$ & 25 & 26 & 25 & 38 & 4 & 3 & 5 & 7 & 24 \\
\hline
\end{tabular}

${ }^{1}$ Means followed by the same letters in the column do not differ by the Tukey's test at $\mathrm{P}<0.05$.

Table 5 - Green ear yield, length and diameter of four maize cultivars from field subplots under different weed control methods (means over maize cultivars) ${ }^{\underline{1}}$

\begin{tabular}{|c|c|c|c|c|c|c|c|c|c|}
\hline \multirow{2}{*}{$\begin{array}{l}\text { Weed control } \\
\text { methods }\end{array}$} & \multicolumn{2}{|c|}{$\begin{array}{c}\text { Marketable green ears } \\
\text { with husks }\end{array}$} & \multicolumn{2}{|c|}{$\begin{array}{c}\text { Marketable green ears } \\
\text { without husks }\end{array}$} & \multicolumn{2}{|c|}{$\begin{array}{c}\text { Ear diameter } \\
(\mathrm{cm})\end{array}$} & \multicolumn{2}{|c|}{$\begin{array}{l}\text { Ear length } \\
(\mathrm{cm})\end{array}$} & \multirow{2}{*}{$\begin{array}{l}\text { Number of } \\
\text { husks ear }^{-1}\end{array}$} \\
\hline & Number ha ${ }^{-1}$ & $\begin{array}{c}\text { Yield } \\
\left(\mathrm{kg} \mathrm{ha}^{-1}\right)\end{array}$ & Number ha ${ }^{-1}$ & $\begin{array}{c}\text { Yield } \\
\left(\mathrm{kg} \mathrm{ha}^{-1}\right)\end{array}$ & (+) husks & $(-)$ husks & (+) husks & (-) husks & \\
\hline Hand-weeding & $38.403 \mathrm{a}$ & $9.734 \mathrm{a}$ & $30.535 \mathrm{a}$ & $5.645 \mathrm{a}$ & $5.5 \mathrm{a}$ & $4.4 \mathrm{a}$ & $29.0 \mathrm{a}$ & $18.9 \mathrm{a}$ & $10.7 \mathrm{a}$ \\
\hline No-weeding & $24.594 \mathrm{~b}$ & $5.247 \mathrm{~b}$ & $18.654 \mathrm{~b}$ & $2.872 \mathrm{~b}$ & $5.2 \mathrm{~b}$ & $4.3 \mathrm{~b}$ & $27.9 \mathrm{~b}$ & $17.0 \mathrm{~b}$ & $9.8 \mathrm{~b}$ \\
\hline With cowpea & $24.390 \mathrm{~b}$ & $5.093 \mathrm{~b}$ & $19.136 \mathrm{~b}$ & $3.176 \mathrm{~b}$ & $5.1 \mathrm{~b}$ & $4.3 \mathrm{~b}$ & $27.5 \mathrm{~b}$ & $17.2 \mathrm{~b}$ & $10.1 \mathrm{a}$ \\
\hline $\mathrm{CVb}(\%)$ & 26 & 28 & 26 & 34 & 5 & 4 & 5 & 6 & 13 \\
\hline
\end{tabular}

11 Means followed by the same letters in the column do not differ by the Tukey's test at $\mathrm{P}<0.05$. 
weed-free plots (Tables 5 and 7). Infesting weed community interference may reduce maize ear diameter and ear length as well (Rossi et al., 1996).

Cultivar and weed control treatment interaction effects on grain yields occurred, reflected by the effects on number of ears per hectare (Table 8). In the weed-free-subplots, the best cultivar was 'BA 8512', although it was not significantly different from 'BA 9012'; in the non-weeded subplots, the best cultivars were 'BA 8512' and 'BA 9012'. In the cowpeaintercropped subplots, the cultivars'BA 8512' and 'EX 6004' were the best ones, although not significantly different from 'BA 9012'. 'EX 4001' showed the lowest grain yield mean values in all treatments, although not significantly different from other cultivars' means (Table 8). On the other hand, 'BA 8512' and 'BA 9012 showed good behavior under the three competition conditions studied. Therefore,

Table 6 - Ear characteristics of four maize cultivars: average number of grain rows per ear; number of grains per ear; 100-seed weight; ear and cob diameter; grain width and height and thickness from field plots under different weed control methods (means over weed control methods) ${ }^{\mathrm{L}}$

\begin{tabular}{|c|c|c|c|c|c|c|c|c|}
\hline Maize cultivar & $\begin{array}{c}\text { Number of } \\
\text { grain rows } \\
\text { per ear }^{-1}\end{array}$ & $\begin{array}{c}\text { Number of } \\
\text { grains per } \\
\text { ear }^{-1}\end{array}$ & $\begin{array}{c}100 \text {-seed } \\
\text { weight }(\mathrm{g})\end{array}$ & $\begin{array}{l}\text { Ear diameter } \\
(\mathrm{cm})\end{array}$ & $\begin{array}{l}\text { Cob diameter } \\
(\mathrm{cm})\end{array}$ & $\begin{array}{c}\text { Grain } \\
\text { thickness } \\
(\mathrm{mm})\end{array}$ & $\begin{array}{l}\text { Grain height } \\
(\mathrm{mm})\end{array}$ & $\begin{array}{l}\text { Grain width } \\
\quad(\mathrm{mm})\end{array}$ \\
\hline BA 8512 & $14.58 \mathrm{a}$ & $387 \mathrm{a}$ & $26.8 \mathrm{~b}$ & $4.2 \mathrm{a}$ & $4.2 \mathrm{a}$ & $4.8 \mathrm{a}$ & $10.4 \mathrm{a}$ & $8.4 \mathrm{c}$ \\
\hline BA 9012 & $14.24 \mathrm{ab}$ & $360 \mathrm{ab}$ & $27.4 \mathrm{~b}$ & $4.3 \mathrm{a}$ & $4.3 \mathrm{a}$ & $4.6 \mathrm{a}$ & $10.6 \mathrm{a}$ & $8.5 \mathrm{c}$ \\
\hline EX 4001 & $13.80 \mathrm{~b}$ & $321 \mathrm{c}$ & $27.0 \mathrm{~b}$ & $4.3 \mathrm{a}$ & $4.3 \mathrm{a}$ & $4.7 \mathrm{a}$ & $10.8 \mathrm{a}$ & $8.9 \mathrm{~b}$ \\
\hline EX 6004 & $13.06 \mathrm{c}$ & $325 \mathrm{bc}$ & $31.1 \mathrm{a}$ & $4.2 \mathrm{a}$ & $4.2 \mathrm{a}$ & $4.7 \mathrm{a}$ & $11.2 \mathrm{a}$ & $9.4 \mathrm{a}$ \\
\hline $\mathrm{CVa}(\%)$ & 4 & 10 & 7 & 4 & 5 & 7 & 7 & 4 \\
\hline
\end{tabular}

${ }^{1 /}$ Means followed by the same letters in the column do not differ by the Tukey's test at $\mathrm{P}<0.05$.

Table 7 - Ear characteristics of four maize cultivars: average number of grain rows per ear; number of grains per ear; 100-seed weight; ear and cob diameter; grain width and height and thickness from field plots under different weed control methods (means over maize cultivars) ${ }^{1}$

\begin{tabular}{|c|c|c|c|c|c|c|c|c|}
\hline $\begin{array}{l}\text { Weed control } \\
\text { methods }\end{array}$ & $\begin{array}{c}\text { Number of } \\
\text { grain rows } \\
\text { per ear }^{-1}\end{array}$ & $\begin{array}{c}\text { Number of } \\
\text { grains per } \\
\text { ear }^{-1}\end{array}$ & $\begin{array}{l}100 \text {-seed } \\
\text { weight }(\mathrm{g})\end{array}$ & $\begin{array}{l}\text { Ear diameter } \\
(\mathrm{cm})\end{array}$ & $\begin{array}{l}\text { Cob diameter } \\
(\mathrm{cm})\end{array}$ & $\begin{array}{l}\text { Grain } \\
\text { thickness } \\
(\mathrm{mm})\end{array}$ & $\begin{array}{c}\text { Grain height } \\
(\mathrm{mm})\end{array}$ & $\begin{array}{l}\text { Grain width } \\
\quad(\mathrm{mm})\end{array}$ \\
\hline Hand-weeding & $14.32 \mathrm{a}$ & $403 \mathrm{a}$ & $31.2 \mathrm{a}$ & $4.5 \mathrm{a}$ & $2.6 \mathrm{a}$ & $4.7 \mathrm{a}$ & $11.2 \mathrm{a}$ & $8.9 \mathrm{a}$ \\
\hline No-weeding & $13.73 \mathrm{~b}$ & $327 \mathrm{~b}$ & $26.5 \mathrm{~b}$ & $4.1 \mathrm{~b}$ & $2.5 \mathrm{~b}$ & $4.7 \mathrm{a}$ & $10.4 \mathrm{~b}$ & $8.7 \mathrm{a}$ \\
\hline With cowpea & $13.71 \mathrm{~b}$ & $316 \mathrm{~b}$ & $26.6 \mathrm{~b}$ & $4.1 \mathrm{~b}$ & $2.5 \mathrm{~b}$ & $4.7 \mathrm{a}$ & $10.7 \mathrm{~b}$ & $8.9 \mathrm{a}$ \\
\hline $\mathrm{CVb}(\%)$ & 4 & 11 & 7 & 4 & 5 & 7 & 5 & 5 \\
\hline
\end{tabular}

${ }^{\Perp}$ Means followed by the same letters in the column do not differ by the Tukey's test at $\mathrm{P}<0.05$.

Table 8 - Grain and ear yielding of four maize cultivars from field plots under different weed control methods (means over weed control methods) ${ }^{\underline{\prime}}$

\begin{tabular}{|c|c|c|c|c|c|c|}
\hline \multirow{3}{*}{ Maize cultivar } & \multicolumn{3}{|c|}{ Grain yield $\left(\mathrm{kg} \mathrm{ha}^{-1}\right)$} & \multicolumn{3}{|c|}{ Number of ears ha ${ }^{-1}$} \\
\hline & \multicolumn{3}{|c|}{ Weed control methods } & \multicolumn{3}{|c|}{ Weed control methods } \\
\hline & Hand-weeding & No-weeding & With cowpea & Hand-weeding & No-weeding & With cowpea \\
\hline BA 8512 & $7.080 \mathrm{aA}$ & $3.980 \mathrm{bA}$ & $3.650 \mathrm{bA}$ & $54.336 \mathrm{aA}$ & $50.644 \mathrm{abA}$ & $47.094 \mathrm{bA}$ \\
\hline BA 9012 & $5.640 \mathrm{aAB}$ & $4.010 \mathrm{bA}$ & $3.140 \mathrm{bAB}$ & $51.294 \mathrm{aAB}$ & $51.309 \mathrm{aA}$ & $45.288 \mathrm{aA}$ \\
\hline EX 4001 & $4.590 \mathrm{aB}$ & $2.170 \mathrm{bB}$ & $1.770 \mathrm{bB}$ & $41.160 \mathrm{aC}$ & $40.574 \mathrm{aB}$ & $35.016 \mathrm{aB}$ \\
\hline EX 6004 & $5.190 \mathrm{aB}$ & $3.400 \mathrm{bAB}$ & $4.050 \mathrm{bA}$ & $43.240 \mathrm{aBC}$ & $41.826 \mathrm{aB}$ & $46.163 \mathrm{aA}$ \\
\hline $\mathrm{CVa}(\%)$ & \multicolumn{3}{|c|}{29} & \multicolumn{3}{|c|}{14} \\
\hline $\mathrm{CVb}(\%)$ & \multicolumn{3}{|c|}{16} & \multicolumn{3}{|c|}{9} \\
\hline
\end{tabular}

$\underline{1}$ Means followed by the same small letters in the lines and capital letters in the columns do not differ by the Tukey's test at $\mathrm{P}<0.05$. 
these results suggested that 'BA 9012' and ' $\mathrm{EX}$ 6004' showed to be better adapted to the specific weed competition conditions in the present experiment, indicating that they can be considered weed tolerant maize genotypes and superior competitors. Similar observations were reported by Begna et al. (2001), Ford \& Pleasant (1994) and Rossi et al. (1996). The interactions between maize cultivar and weed plants will depend on the seasonal year, which will have an affect on weed plant population (Ford \& Pleasant, 1994). The superiority of some maize hybrids in the presence of weeds may not be due to their ability to reduce weed growth through better plant architecture or higher water and nutrient competition, but rather to their higher ability to maintain grain production in the presence of high weed incidence (Ford \& Pleasant, 1994).

The weeds reduced maize green ear and grain yields, as well as other maize characteristics, in the non-weeded subplots (Tables 4 and 8 ). In the intercropped subplots, weeds plus the cowpea cultivar promoted similar effect of non-weeding treatment on most of the maize characteristics evaluated (Tables 4 and 8). The cowpea cultivar acted like a weed: it reduced maize yields and did not produce any grain. It is reasonable to state that maize intercropped with cowpea aim at a better utilization of environmental resources but these results showed no advantages for maize.

It can be concluded that ten weed species predominated in the experiment, many of which belonging to the Poaceae family. No interactions were found between methods of weed control and maize cultivars for most variables evaluated; and plants from handweeded subplots showed superior mean values compared to plants from non-weeded and intercropped subplots, both of which did not differ from each other. Cowpea was inefficient in controlling weeds, reducing maize yields and not producing any grain. Maize cultivars 'BA 8512' and 'BA 9012 showed the highest mean green ear yield, and the highest grain yield in the hand-weeded, no-weeded and intercropped subplots. On the other hand, maize cultivar 'EX 6004' showed such high averages only in no-weeded and intercropped subplots. 'EX 4001 had the worst performance in these variables for hand-weeded, no-weeded ant intercropped subplots (Table 8).

\section{LITERATURE CITED}

AFLAKPUI, G. K. S.; GREGORY, P. J.; FROUD-

WILLIAMS, R. J.Growth and biomass partitioning of maize during vegetative growth in response to Striga hermonthica infection and nitrogen supply. Exper. Agric., v. 38, p. 265276, 2002.

BEGNA, S. H. et al. Morphology and yield response to weed pressure by corn hybrids differing in canopy architecture. Eur. J. Agron., v. 14, n. 4, p. 293-302, 2001.

BRASIL. Ministério da Agricultura, Pecuária e Abastecimento - MAPA. Manual de métodos de análise de solo. 2.ed. Rio de Janeiro: Embrapa/CNPS, 1997. 212 p.

BUHLER, D. D. Weed population responses to weed control practices. I. Seed bank, weed populations, and crop yields. Weed Sci., v. 47, n. 4, p. 416-422, 1999.

CALLAWAY, M. B. A compendium of crop varietal tolerance to weeds. Am. J. Altern. Agric., v. 4, n. 1, p. 169180, 1992.

EMPRESA BRASILEIRA DE PESQUISA AGROPECUÁRIA - EMBRAPA. Sistema brasileiro de classificação de solos. Brasília: Serviço de Produção de Informação, 1999. 412 p.

FORD, G. T.; PLEASANT, J. Competitive abilities of six corn (Zea mays L.) hybrids with four weed control practices. Weed Technol., v. 8, n. 3, p. 124-128, 1994.

FUKAI, S.; TRENBATH, B. R. Processes determining intercrop productivity and yields of components crops. Field Crops Res., v. 34, n. 3-4, p. 247-271, 1993.

KUCHINDA, N. C. et al. On-farm evaluation of improved maize varieties intercropped with some legumes in the control of Striga in the Northern Guinea savanna of Nigeria. Crop. Prot., v. 22, p. 533-538, 2003.

LIEBMAN, M.; DAVIS, A.S. Integration of soil, crop and weed management in low-input farming systems. Weed Res., v. 40, n. 1, p. 27-47, 2000.

LIEBMAN, M.; DYCK, E. Crop rotation and intercropping strategies for weed management. Ecol. Appl., v. 3, n. 1, p. 92-122, 1993.

LINDQUIST, J. L.; MORTENSEN, D. A. Tolerance and velvetleaf (Abutilon theophrasti) suppressive ability of two old and modern corn (Zea mays) hybrids. Weed Sci., v. 46, p. $569574,1998$. 
MENALLED, F. D.; GROSS, K. L.; HAMMOND, M. Weed aboveground and seedbank community reponses to agricultural management systems. Ecol. Appl., v. 11, n. 6, p. $15861601,2001$.

OLASANTAN, F. O; LUCAS, E. O.; EZUMAH, H. C. Effects of intercropping and fertilizer application on weed control and performance of cassava and maize. Field Crops Res., v. 39, n. 1, p. 63-69, 1994.

\section{RIBEIRO JÚNIOR, J. I. Análises estatísticas no SAEG.} Viçosa, MG: Universidade Federal de Viçosa, 2001.

ROSSI, I. H. et al. Interferência das plantas daninhas sobre algumas características agronômicas e a produtividade de sete cultivares de milho. Planta Daninha, v. 14, n. 2, p. 134148, 1996.

SKÓRA NETO, F. Controle de plantas daninhas através de coberturas verdes consorciadas com milho. Pesq. Agropec. Bras., v. 28, n. 10, p. 1165-1171, 1993.

SILVA, P. S. L.; SILVA, E. S.; MESQUITA, S. S. X. Weed control and green ear yield in maize. Planta Daninha, v. 22, n. 1, p. 137-144, 2004.
SINOQUET, H.; CALDWELL, R. M. Estimation of light capture and partitioning in intercropping systems. In: SINOQUET, H.; CRUZ, P. (Eds.). Ecophysiology of tropical intercropping. Paris: Institute Nationale de La Researche Agronomique (INRA), 1995. p. 79-80.

SOUZA, L. C. F. Época de gradagem em relação à semeadura e sistema de controle de plantas daninhas no desempenho da cultura do milho (Zea mays L.). 1994.

129 f. Tese (Doutorado em Fitotecnia) - Universidade Federal de Lavras, Lavras, 1994.

STANIFORTH, D. W. Responses of corn hybrids to yellow foxtail competition. Weeds, v. 9, n. 1, p. 132-136, 1961.

TOLLENAAR, M. et al. Effects of weed interference and soil nitrogen on four maize hybrids. Agron. J., v. 86, p. 596601, 1994.

VANDERMEER, J. et al. Global change and multi-species agroecosystems: concepts and issues. Agric. Ecosyst. Environ., v. 67, n. 1, p. 1-22, 1998. 